Change in Serum Lipid Levels in Transplant Patients after Dieting for One Month

\begin{tabular}{|c|c|c|c|c|c|c|c|c|c|c|c|c|}
\hline \multirow{2}{*}{$\begin{array}{l}\text { Case } \\
\text { No. }\end{array}$} & \multirow[t]{2}{*}{ Sex } & \multirow{2}{*}{$\begin{array}{c}\text { Age } \\
\text { (Years) }\end{array}$} & \multirow{2}{*}{$\begin{array}{c}\text { Time since } \\
\text { Transplantation } \\
\text { (Months) }\end{array}$} & \multirow{2}{*}{$\begin{array}{c}\text { Plasma } \\
\text { Creatinine } \\
(\mu \mathrm{mol} / \mathrm{l})\end{array}$} & \multicolumn{2}{|c|}{$\underset{(\mathrm{mmol} / \mathrm{l})}{\text { Plasma Cholesterol }}$} & \multicolumn{2}{|c|}{$\begin{array}{c}\text { Plasma Triglyceride } \\
(\mathrm{mmol} / \mathrm{l})\end{array}$} & \multicolumn{2}{|c|}{$\begin{array}{c}\text { Pre- } \beta \text {-lipoproteins } \\
(\%)\end{array}$} & \multicolumn{2}{|c|}{$\underset{(\mathrm{kg})}{\text { Body Weight }}$} \\
\hline & & & & & Before & After & Before & After & Before & After & Before & After \\
\hline $\begin{array}{l}1 \\
2 \\
3 \\
4 \\
5 \\
6\end{array}$ & $\begin{array}{l}\text { F. } \\
\text { M. } \\
\text { M. } \\
\text { M. } \\
\text { M. } \\
\text { F. }\end{array}$ & $\begin{array}{l}31 \\
30 \\
34 \\
36 \\
42 \\
33\end{array}$ & $\begin{array}{r}14 \\
10 \\
15 \\
7 \\
18 \\
13\end{array}$ & $\begin{array}{l}106 \\
141 \\
133 \\
133 \\
141 \\
115\end{array}$ & $\begin{array}{l}4 \cdot 0 \\
4 \cdot 7 \\
7 \cdot 3 \\
8 \cdot 0 \\
7 \cdot 3 \\
7 \cdot 0\end{array}$ & $\begin{array}{l}4 \cdot 1 \\
5 \cdot 7 \\
3.9 \\
6 \cdot 3 \\
6.5 \\
7 \cdot 0\end{array}$ & $\begin{array}{l}2 \cdot 3 \\
3 \cdot 8 \\
4 \cdot 6 \\
2 \cdot 5 \\
5 \cdot 1 \\
3 \cdot 6\end{array}$ & $\begin{array}{l}1.5 \\
2.0 \\
1.9 \\
1.8 \\
1.9 \\
1.8\end{array}$ & $\begin{array}{l}26 \\
31 \\
40 \\
31 \\
45 \\
25\end{array}$ & $\begin{array}{l}21 \\
16 \\
22 \\
10 \\
19 \\
19\end{array}$ & $\begin{array}{l}63 \cdot 0 \\
57.0 \\
71 \cdot 0 \\
74.0 \\
74.5 \\
64.5\end{array}$ & $\begin{array}{l}62 \cdot 0 \\
54 \cdot 6 \\
65 \cdot 8 \\
73 \cdot 4 \\
70 \cdot 0 \\
62 \cdot 5\end{array}$ \\
\hline \multicolumn{2}{|c|}{ Mean \pm S.D. } & $34 \cdot 3$ & $12 \cdot 3$ & 124 & $6 \cdot 3 \pm 1 \cdot 6$ & $5 \cdot 6 \pm 1 \cdot 3$ & $3 \cdot 7 \pm 1 \cdot 1$ & $1 \cdot 8 \pm 0.2$ & $33 \pm 7$ & $17 \pm 4$ & $67 \cdot 3 \pm 6 \cdot 9$ & $64 \cdot 7 \pm 6 \cdot 6$ \\
\hline \multicolumn{2}{|c|}{ Significance } & & & & \multicolumn{2}{|c|}{ N.S. } & \multicolumn{2}{|c|}{$P<0.01$} & \multicolumn{2}{|c|}{$P<0.01$} & \multicolumn{2}{|c|}{ N.S. } \\
\hline
\end{tabular}

and severe fasting hypertriglyceridaemia 7-18 months (mean 12.3 months) after renal transplantation. All were on a free diet and their body weight was higher than ideal before treatment.

\section{Diet and Results}

The suggested diet was: breakfast, milk $200 \mathrm{~g}$; lunch, spaghetti or rice $50 \mathrm{~g}$, beef, veal, or poultry $150 \mathrm{~g}$ or lean ham $110 \mathrm{~g}$, vegetables (carrots, cabbages, tomatoes, lettuce) $150 \mathrm{~g}$, fruit (apples, pears, peaches, oranges, apricots, mandarines) $150 \mathrm{~g}$, and olive-oil $15 \mathrm{~g}$; and supper, spaghetti or rice $50 \mathrm{~g}$, lean cheese $70 \mathrm{~g}$, vegetables $150 \mathrm{~g}$, fruit $150 \mathrm{~g}$, and olive-oil $15 \mathrm{~g}$. Butter, maize oil, coconut oil, margarine, alcohol, fruit juices, sweets, and sugar were forbidden. This diet contained about $7 \mathrm{MJ}(1700 \mathrm{kcal}), 130 \mathrm{~g}$ carbohydrate, $70 \mathrm{~g}$ protein, and $100 \mathrm{~g}$ fat daily.

After a month on the diet the lipid pattern returned to normal (table). Then, to avoid excessive weight loss in individual patients, an increase of $1 \cdot 7-2 \cdot 5$ MJ $(400-600 \mathrm{kcal})$ was allowed, with the addition of protein and some fat After six months on this regimen the lipid pattern remained in the normal range, with little fluctuation in body weight.

\section{Discussion}

Thus even in transplanted, corticodependent patients such a diet can correct hypertriglyceridaemia. This can be of practical importance, since apart from graft rejection and infection cardiovascular disease is the most common cause of death after renal transplantation. ${ }^{5}$ Moreover, hyperlipidaemia could contribute to the severity of renal vascular disease in kidney transplant rejection or disfunction. ${ }^{2}$

We conclude that the transplanted, hypertriglyceridaemic patient should be told of the danger of a high calorie, high carbohydrate diet. This might in some cases improve the long-term prognosis.

1 Casaretto, A., et al., Lancet, 1974, 1, 481.

2 Edwards, K. D. G., and Charlesworth, J. A., Lancet, 1973, 1, 1192.

3 Robertson, R. P., et al., fournal of Clinical Investigation, 1973, 52, 1620.

4 Levy, R. I., Morganroth, J., and Rifkind, B. M., New England fournal of Medicine, 1974, 290, 1295.

5 Lowrie, E. G., et al., New England fournal of Medicine, 1973, 288, 863.

Nephrology and Dialysis Unit, Polyclinic Hospital of Milan, 20122 Milan, Italy

CLAUDIO PONTICELLI, M.D., Chief of Unit

ALBERTO CANTALUPPI, M.D., Assistant in Nephrology

Institute of Clinical Medicine III, University of Milan, 20122 Milan, Italy

GIANLUIGI BARBI, M.D., Assistant Professor of Medicine

GIORGIO ANNONI, M.D., Assistant in Medicine

FRANCESCO MAURI, M.D., Assistant in Medicine

\section{Metastatic Carcinoma Causing Haematemesis}

We describe a case of haematemesis due to gastric metastases from bronchial carcinoma. Secondary spread of carcinoma to the stomach is unusual, and haematemesis from this cause has not been reported.

\section{Case Report}

A 59-year-old engineer was admitted with a history of vomiting blood. Nine weeks previously he had developed low back pain, for which he had taken phenylbutazone. He had smoked 15 cigarettes per day. He was obese and shocked. There was slight epigastric tenderness on abdominal palpation but no masses could be felt. Rectal examination demonstrated melaena stool The chest was clinically clear and the remainder of the physical examination was normal. Haemoglobin was $10 \cdot 3 \mathrm{~g} / \mathrm{dl}$, P.C.V. $25 \cdot 5 \%$, W.B.C. $15 \cdot 4 \times 10^{\circ} / 1$ platelet count and prothrombin time normal, blood urea $40.7 \mathrm{mmol} / \mathrm{l}$ $(245 \mathrm{mg} / 100 \mathrm{ml})$, serum electrolytes normal, the $x$-ray film showed a large peripheral left lower zone opacity and the right hemidiaphragm was raised. Blood transfusion was started and continued for the next 36 hours, while repeated haematemeses occurred. An emergency barium meal showed no abnormality. Bronchopneumonia developed and he died four days after admission.

At necropsy on opening the chest a solitary solid round pale tumour $8 \mathrm{~cm}$ wide was found in the peripheral part of the left upper lobe. It was in contact with the chest wall with invasion and pathological fracture of adjacent ribs. Further extrapleural tumour masses were seen in the right hemithorax which had not been conspicuous in the chest $x$-ray film. Below the diaphragm a large tumour had replaced most of the right kidney, with growth filling the main renal vein. Secondary deposits were also found in the other kidney, liver, spleen, para-aortic lymph nodes, and thoracolumbar vertebrae. The stomach contained fresh blood derived from two ulcers on the posterior wall of its body, 1.2 and $0.5 \mathrm{~cm}$ wide. They were circular with hard, smooth rolled edges. The small and large intestines were normal. Histological examination showed all lesions to be derived from an oat-cell carcinoma of the bronchus. The site of bleeding in the gastric secondary deposits was from ulcerated submucosal veins distended with growth.

\section{Discussion}

Carcinoma of the stomach may be primary or secondary. Though bloodborne metastases to the stomach have been reported as incidental findings in several large necropsy series, ${ }^{12}$ we have not found reports of haematemesis from secondary carcinomatous deposits in the stomach. The most common tumours that spread to the stomach through the blood stream are melanomas and carcinomas of the breast and lung. Tumours of the testis and thyroid also behave in this way. ${ }^{1}$ Those lung neoplasms which are likely to spread are undifferentiated or adenocarcinomas rather than squamous cell carcinomas. Our patient had the oat-cell variety. Spiro ${ }^{3}$ states that if carcinoma of the lung spreads to the stomach it is usually as a diffuse submucosal growth; rarely, its appearance may simulate lymphoma with large ulcerating lesions. The stomach lesions in our patient had the appearances of umbilicated secondary deposits, which usually occur in secondary deposits from a melanoma.

Clinically the case demonstrates the necessity for a routine chest radiograph in all cases of haematemesis. Faced with the normal barium meal, gastroscopy and biopsy might have been helpful in reaching an earlier diagnosis, though this would not have affected the final outcome. The case was complicated by the history of phenylbutazone intake for low back pain, but there was no evidence of erosive gastritis at necropsy. Vertebral metastases were the cause of the back pain and bilateral renal metastases together with blood in the gastrointestinal tract the cause of the high blood urea. case.

We would like to thank Dr. D. N. Phear for allowing us to publish this

1 Willis, R. A., The Spread of Tumours in the Human Body. London, Butterworth, 1952.

2 Abrahms, H. L., Spiro, R., and Goldstein, N., Cancer, 1950, 3, 74.

${ }_{3}$ Spiro, H. M., Clinical Gastroenterology. Toronto, Macmillan Company, 1970.

St. Albans City Hospital, St. Albans, Hertfordshire

R. EDWARDS, M.R.C.P., Medical Registrar

G. ROYLE, F.R.C.S., Surgical Registrar 